IRENEUSZ DRABIK

Uniwersytet Pedagogiczny w Krakowie, Polska - Pedagogical University of Cracow, Poland

\title{
Przedsiębiorczość międzynarodowa w teorii internacjonalizacji przedsiębiorstwa
}

\section{International Entrepreneurship in the Theory of Enterprise Internationalisation}

Streszczenie: Celem artykułu jest przedstawienie teoretycznych podstaw kategorii przedsiębiorczości międzynarodowej. W artykule wykorzystano metodę analizy krytycznej. Przedsiębiorczość międzynarodowa została przedstawiona jako obszar wspólny dwóch domen badawczych: przedsiębiorczości i biznesu międzynarodowego. W pierwszej kolejności scharakteryzowano konwencjonalny (tradycyjny) model internacjonalizacji (tzw. model uppsalski - sekwencyjny, ewolucyjny) i możliwe odniesienia do przedsiębiorczości międzynarodowej. Pomimo iż w tradycyjnym podejściu do internacjonalizacji problematyka przedsiębiorczości nie jest analizowana (uwaga jest skupiona przede wszystkim na stopniowym gromadzeniu wiedzy i doświadczenia oraz na samym procesie umiędzynarodowienia przedsiębiorstwa), to w fakcie poszukiwania i ewolucyjnego wchodzenia na kolejne rynki zagraniczne, a także stosowania coraz bardziej zaawansowanych form internacjonalizacji można dopatrywać się elementów zachowań przedsiębiorczych. Następnie przedstawiono przedsiębiorczość międzynarodową w kontekście koncepcji tzw. wczesnej internacjonalizacji przedsiębiorstw, której praktycznym przejawem jest funkcjonowanie tzw. przedsiębiorstw globalnych od założenia (born globals). Zazwyczaj - choć nie jest to regułą - są to małe i średnie przedsiębiorstwa, które funkcjonują w branżach nowoczesnych technologii i od początku swego istnienia zorientowane są na obsługę rynku międzynarodowego. Wczesna internacjonalizacja przedsiębiorstwa, $\mathrm{w}$ tym przede wszystkim szczególne charakterystyki założycieli i menedżerów born globals, takie jak wizja globalna, wcześniejsze doświadczenie międzynarodowe oraz liczne kontakty osobiste i zawodowe, utożsamiana jest z istotą współczesnego rozumienia przedsiębiorczości międzynarodowej.

Abstract: The aim of the paper is to present the theoretical foundations of international entrepreneur-
ship. For this purpose, the critical analysis method is used. International entrepreneurship is presented
as the area common to two research domains: entrepreneurship and international business. At first, a de-
scription is provided of the traditional model of internationalisation (known as the Uppsala model which
is evolutionary and sequential in nature) and of possible references to international entrepreneurship.
Although the issues of entrepreneurship are not analysed within the traditional approach to internation-
alisation (where the focus is primarily on gradual gathering of knowledge and gaining experience, and on
the process of the enterprise internalisation itself), elements of entrepreneurial behaviour can be found
in the mere fact of searching for and evolutionary entering new foreign markets or in the use of more 
advanced forms of internationalisation. Next, international entrepreneurship is presented in the context of what is referred to as early internationalisation of enterprises - a phenomenon that manifests itself by the functioning of "born globals". It is not a rule, but these are usually small and medium enterprises operating in the high-tech industries and oriented towards servicing the international market right from the moment they are started. The enterprise early internationalisation, including first of all some unique characteristics of the founders and managers of born globals, such as having a global vision, previous experience in an international environment and numerous personal and professional contacts, is equated with the essence of a modern understanding of international entrepreneurship.

Słowa kluczowe: born globals; internacjonalizacja przedsiębiorstwa; przedsiębiorczość międzynarodowa; zarządzanie międzynarodowe

Keywords: born globals; enterprise internationalisation; international entrepreneurship; international management

Otrzymano: 8 listopada 2017

Received: 8 November 2017

Zaakceptowano: 27 maja 2018

Accepted: 27 May 2018

Sugerowana cytacja/Suggested citation:

Drabik, I. (2018). Przedsiębiorczość międzynarodowa w teorii internacjonalizacji przedsiębiorstwa. Przedsiębiorczość - Edukacja [Entrepreneurship - Education], 14, 165-176. DOI: $10.24917 / 20833296.14 .12$

\section{Wstęp}

Tradycyjnie przedsiębiorczość łączono z małymi i średnimi przedsiębiorstwami, rozpoczynającymi działalność na rynku krajowym. Internacjonalizację domyślnie uznawano za innowację, a więc kolejne działanie przedsiębiorcze, tyle że dotyczące rynku międzynarodowego. Co więcej, badacze problematyki przedsiębiorczości nie poświęcali internacjonalizacji wiele uwagi. Dopiero rosnąca liczba doniesień na temat tzw. wczesnej internacjonalizacji małych i średnich przedsiębiorstw, począwszy od lat 80 . XX w., skłoniła ich do bliższego przyjrzenia się temu zjawisku. Mimo że obecnie obszar badawczy przedsiębiorczości międzynarodowej obejmuje nie tylko internacjonalizację małych i średnich, nowo tworzonych przedsiębiorstw, ale także działania podejmowane przez duże przedsiębiorstwa istniejące na rynku od wielu lat, jak również organizacje non profit, to pierwszym zagadnieniem z tego obszaru, jakim w sposób istotny się zainteresowano, było zjawisko tzw. wczesnej internacjonalizacji przedsiębiorstw.

$\mathrm{Z}$ drugiej strony, także środowisko badawcze związane z zarządzaniem międzynarodowym i internacjonalizacją przedsiębiorstwa początkowo niezbyt wiele uwagi poświęcało przedsiębiorczości. W konwencjonalnym (tradycyjnym) podejściu do internacjonalizacji przedsiębiorstwa, w ramach którego największą popularność zdobył tzw. model uppsalski (podkreślający sekwencyjny, ewolucyjny charakter procesu internacjonalizacji), główna uwaga badaczy skupiała się na problemie gromadzenia wiedzy i doświadczenia umożliwiających wchodzenie na kolejne rynki zagraniczne z wykorzystaniem coraz bardziej zaawansowanych form internacjonalizacji. Zagadnienie przedsiębiorczości jako takiej nie było wprost artykułowane. Dopiero pojawienie się wspomnianej koncepcji wczesnej internacjonalizacji i przedsiębiorstw globalnych od założenia (born globals), których 
gwałtowny rozwój nastąpił w latach 90. XX w., skutkowało wzrostem zainteresowania problematyką przedsiębiorczości międzynarodowej w innym niż dotychczas zakresie.

\section{Przedsiębiorczość międzynarodowa jako obszar badawczy}

Pojęcie przedsiębiorczości nie ma jednej, ściśle określonej definicji (Wach, 2015). Potrzeba istnienia takiej jest jednak często podkreślana w literaturze przedmiotu (Jones, Coviello, Kwan Tang, 2011). Przedsiębiorczość w różnych swoich formach, do których można zaliczyć podmiot (przedsiębiorcę), postawę czy też formę organizacyjną, jest zaliczana do podstawowych wyrażeń związanych z ekonomią behawioralną, która wykazuje rosnący wpływ na ewolucję teorii zarządzania strategicznego (Polowczyk, 2012; Wach, 2017a). Przedsiębiorczość może być traktowana jako gotowość do podejmowania nowych rozwiązań czy też działanie mające na celu zapewnienie rentowności prowadzonej działalności (Wiatrak, 2008).

Przedsiębiorczość międzynarodowa, będąca w istocie rozszerzeniem pojęcia przedsiębiorczości i zawartej w nim problematyki na działalność w otoczeniu międzynarodowym (rynki zagraniczne), również nie doczekała się jednej, uznanej za podstawową i nadrzędną definicji. W literaturze przedmiotu pojęcie przedsiębiorczości międzynarodowej często stosowane jest intuicyjnie, a niejednokrotnie - nieświadomie. Zazwyczaj utożsamiane jest po prostu z prowadzeniem działalności na rynkach zagranicznych, co wydaje się zawężeniem problematyki (Morawczyński, 2008).

Przedsiębiorczość międzynarodowa może być traktowana jako obszar wspólny dwóch domen badawczych (ryc. 1): przedsiębiorczości i biznesu międzynarodowego, czyli z jednej strony jej podstaw teoretycznych dostarczają teorie i koncepcje przedsiębiorczości, a z drugiej strony - teorie ekonomiczne internacjonalizacji przedsiębiorstwa (Kraśnicka, 2008). Rozwój przedsiębiorczości międzynarodowej jest ściśle powiązany z postępującym procesem internacjonalizacji i globalizacji przedsiębiorstw. Przemiany gospodarki światowej na przełomie XX i XXI wieku oddziaływały nie tylko na warunki funkcjonowania przedsiębiorstw, lecz przede wszystkim wymusiły i wciąż wymuszają zmiany w sposobie

Ryc. 1. Przedsiębiorczość międzynarodowa jako wspólny obszar dwóch domen badawczych

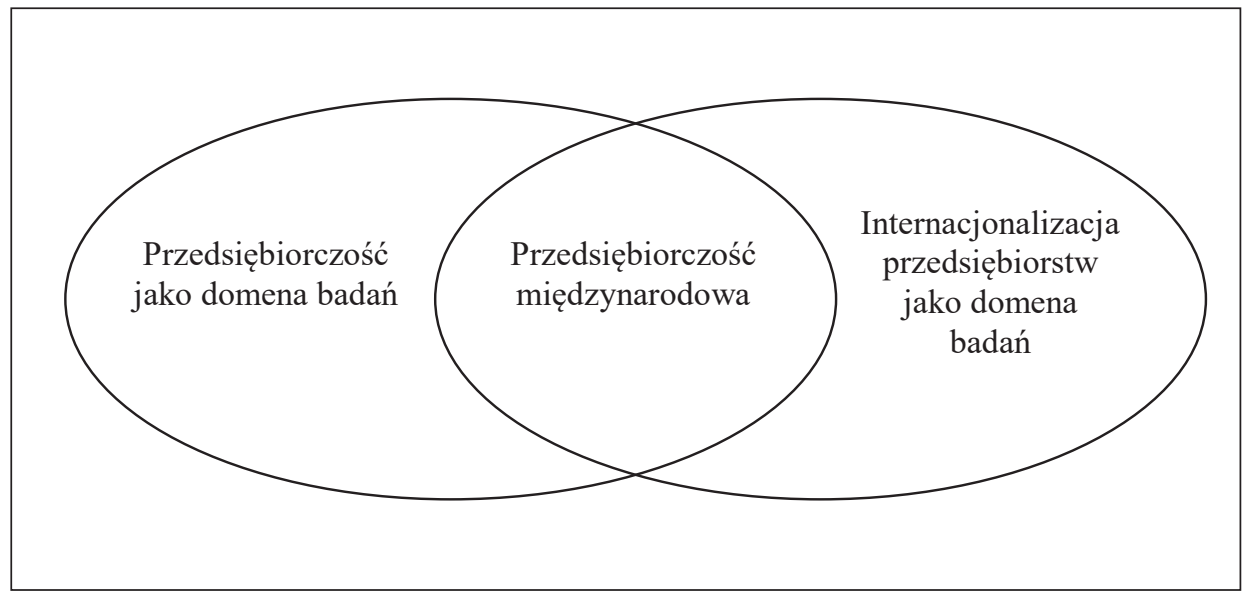

Źródło: Kraśnicka (2008: 13) 
myślenia o zarządzaniu przedsiębiorstwem i przedsiębiorczości (Rymarczyk, 2004; Wach, 2017b). Obserwowane obecnie procesy umiędzynarodowienia i globalizacji oznaczają wzrost liczby i stopnia intensywności powiązań społecznych i gospodarczych pomiędzy poszczególnymi krajami i przedsiębiorstwami. Procesy te należy traktować jako jedne z najważniejszych wyzwań, przed którymi stoją menedżerowie odpowiedzialni za rozwój przedsiębiorstw (Nowacki, 2013).

Przedsiębiorczość międzynarodową można postrzegać jako kombinację takich czynników, jak innowacyjność, proaktywność czy też nieoportunistyczne podejście do ryzyka, które przekraczają granice krajowe i rozwijane są na rynkach zagranicznych (ryc. 2). Pojęcie to może być również stosowane w kontekście wykorzystywania pojawiających się szans w otoczeniu, a czynnikiem wyróżniającym jest ich międzynarodowy charakter. Zasadnicze znaczenie w zrozumieniu przedsiębiorczości ma innowacyjność - pojęcie spopularyzowane przez J. Schumpetera. Znaczenie innowacyjności w przedsiębiorczości związane jest z możliwościami powstawania i rozwoju nowych produktów oraz usług, dzięki którym przedsiębiorstwo, w analizowanym przez nas przypadku - internacjonalizujące swoją działalność, jest bardziej skłonne do podejmowania ryzyka i wykazywania aktywnej postawy w otoczeniu międzynarodowym. Przedsiębiorstwo, które wykazuje się innowacyjnością i dodatkowo sprawnością w działaniu, staje się naturalnym wzorcem i punktem odniesienia dla konkurentów (Nowacki, 2014).

Ryc. 2. Koncepcja przedsiębiorczości międzynarodowej

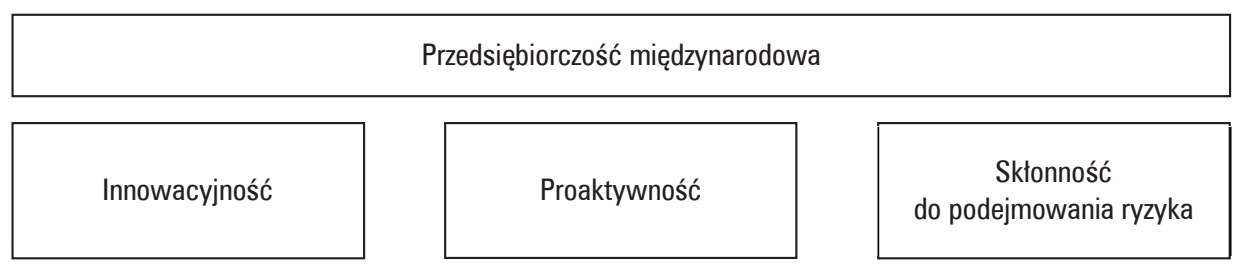

Źródło: Nowacki (2014: 16)

Interesującą próbę przedstawienia podstaw teoretycznych przedsiębiorczości międzynarodowej w szerokim tego pojęcia znaczeniu zaproponował H. Etemad. Według niego przedsiębiorczość międzynarodową należy traktować jako wielopłaszczyznowy, dynamiczny, otwarty, złożony i adaptacyjny system (metamodel). Przedstawione przez niego podstawy teoretyczne obejmują liczne założenia dotyczące w pierwszej kolejności przedsiębiorcy i przedsiębiorczości. Historycznie rzecz ujmując, przedsiębiorca był postrzegany jako agent zmiany w środowisku, w którym działa, i to założenie należy traktować jako kluczowe. Podstawy teoretyczne przedsiębiorczości międzynarodowej wspomniany autor rozważa w czterech płaszczyznach (ryc. 3), mianowicie:

- przedsiębiorcy (wybrane koncepcje i teorie przedsiębiorczości, w tym przedsiębiorcy),

- przedsiębiorstwa (podstawowe teorie firmy - od klasycznych, neoklasycznych, przez behawioralną koncepcję, aż po współczesne teorie, w tym koncepcję przedsiębiorczej firmy),

- rynku (traktowanego jako miejsce: wymiany, alokacji zasobów, odkrywania szans oraz selekcji/weryfikacji twórczych inicjatyw),

- otoczenia międzynarodowego i ogólnego, które na siebie oddziałują i pozostają we wzajemnych relacjach - bezpośrednich i pośrednich (Etemad, 2004. Za: Kraśnicka, 2008). 
Ryc. 3. Podstawowe elementy - płaszczyzny i interakcje pomiędzy nimi w koncepcji przedsiębiorczości międzynarodowej wg H. Etemada

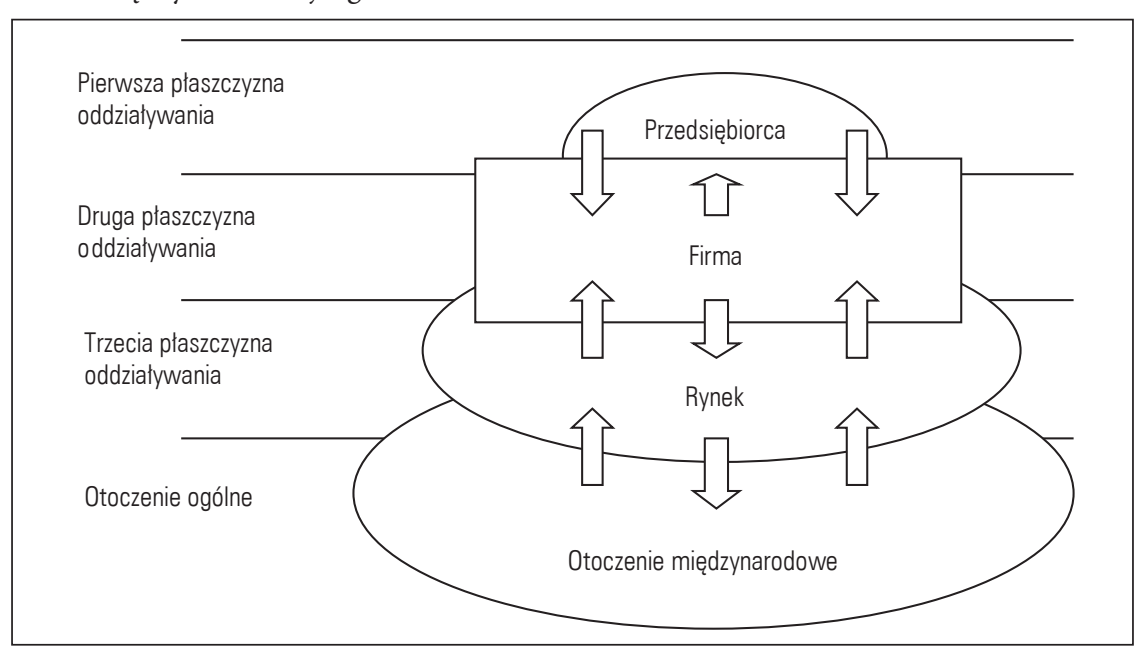

Źródło: Etemad (2004: 30. Za: Kraśnicka, 2008: 16)

Przedsiębiorczość międzynarodowa a konwencjonalny model internacjonalizacji przedsiębiorstwa

Przedsiębiorczość międzynarodowa może być rozpatrywana w kontekście konwencjonalnego podejścia do internacjonalizacji przedsiębiorstwa. Wśród koncepcji internacjonalizacji największą popularność zdobył tzw. model uppsalski, zaproponowany przez pracowników uniwersytetu w Uppsali w Szwecji: J. Johansona i F. Wiedersheima-Paula w 1975 r., a rozwinięty dwa lata później przez J. Johansona i J.E. Vahlnego (Johanson, Wiedersheim-Paul, 1975; Johanson, Vahlne, 1977). Konsekwencją zmian, które zaszły w ramach teorii i praktyki od czasu pojawienia się modelu uppsalskiego w latach 70. XX wieku, jest także jego nowa propozycja, polegająca na tym, że autorzy modelu uppsalskiego zwrócili się w kierunku podejścia sieciowego (Johanson, Vahlne, 2009). Wprawdzie tradycyjny model uppsalski nie traktuje wprost o przedsiębiorczości, lecz uwypukla znaczenie zjawiska uczenia się - gromadzenia wiedzy i doświadczenia, jednak w jego podstawowych założeniach można dopatrywać się elementów zachowań przedsiębiorczych.

Punktem wyjścia konwencjonalnego modelu uppsalskiego jest obserwacja, że w przypadku wielu przedsiębiorstw, w szczególności pochodzących z krajów charakteryzujących się niewielkimi rozmiarami rynku macierzystego (krajowego), typowe zachowanie podmiotu rozwijającego działalność gospodarczą na rynkach zagranicznych cechuje się etapowością zaangażowania w obsługę tych rynków. Internacjonalizacja jest postrzegana jako powolny i stopniowy proces uzależniony od poziomu wiedzy i doświadczenia w obsłudze rynków zagranicznych, którymi dysponuje przedsiębiorstwo. Główną przeszkodą internacjonalizacji jest brak wiedzy o rynkach zagranicznych, powodujący niepewność wśród menedżerów utożsamiających internacjonalizację z dużym ryzykiem. Wynika stąd fundamentalne znaczenie zjawiska uczenia się przedsiębiorstwa. W jego wyniku coraz mniejszy stopień niepewności pozwala na głębsze i intensywniejsze angażowanie się przedsiębiorstwa w operacje na rynkach zagranicznych. Wiedza o rynku ma charakter 
przede wszystkim statyczny, ale decyzja o internacjonalizacji i rozwój działalności w otoczeniu międzynarodowym (wchodzenie na nowe rynki zagraniczne, któremu towarzyszy wykorzystywanie coraz bardziej zaawansowanych form internacjonalizacji) są elementami dynamicznymi jednoznacznie nawiązującymi do zachowań przedsiębiorczych.

Zgodnie z modelem uppsalskim ekspansja zagraniczna jest poprzedzona sukcesem przedsiębiorstwa na rynku macierzystym i jest konsekwencją wielu decyzji podejmowanych w przedsiębiorstwie (model uppsalski przyjmuje więc perspektywę behawioralnej teorii przedsiębiorstwa). Zazwyczaj proces internacjonalizacji rozpoczyna się od obsługi rynków położonych blisko w sensie odległości geograficznej (niewielki dystans geograficzny), a dopiero później - po zgromadzeniu odpowiedniej wiedzy i doświadczenia obejmuje rynki dalsze. Jednocześnie przedsiębiorstwo, wchodząc na rynki zagraniczne, najczęściej rozpoczyna działalność z wykorzystaniem najprostszej formy eksportu pośredniego, a dopiero po upływie pewnego czasu decyduje się na działania wymagające większego zaangażowania, np. w formie zagranicznych inwestycji bezpośrednich (Gorynia, Jankowska, 2007).

W modelu uppsalskim wprowadzono również pojęcie dystansu psychicznego między rynkami, rozumianego jako zestaw czynników (język, kultura, system polityczny, poziom edukacji, poziom rozwoju gospodarczego itp.) utrudniających przepływ informacji między przedsiębiorstwem a obsługiwanymi rynkami zagranicznymi. Dystans psychiczny został uznany za silną determinantę internacjonalizacji również w późniejszych pracach kolejnych autorów zajmujących się internacjonalizacją przedsiębiorstwa (Przybylska, 2009). Dystans psychiczny koreluje z dystansem geograficznym, ale nie można go z nim utożsamiać, istnieją bowiem liczne wyjątki od takiej reguły, jak np. bliskość psychiczna krajów anglosaskich oddalonych geograficznie (Wielka Brytania, USA, Kanada, Australia). Nie powinno się także sprowadzać dystansu psychicznego jedynie do różnic kulturowych, choć czasami używa się pojęcia „dystans geokulturowy” i definiuje go jako „bariery spowodowane odległością geograficzną, różnicami kulturowymi między krajami oraz problemami w komunikacji wynikającymi z różnic społecznych, językowych i związanych z postawami" (Bradley, 1999: 212).

Warto podkreślić, że dystans psychiczny między krajami nie jest wartością stałą, ale zmienia się pod wpływem przeobrażeń poszczególnych czynników wchodzących w jego skład. Można zauważyć zmniejszenie się roli dystansu psychicznego między krajami w warunkach postępujących procesów globalizacji i regionalizacji gospodarki światowej. Dystans psychiczny może maleć wskutek wydarzeń politycznych umożliwiających intensyfikację współpracy społecznej i gospodarczej między krajami. Z powyższego wynika, że procesy społeczne i gospodarcze zachodzące we współczesnej gospodarce światowej, wpływające na zmniejszanie dystansu psychicznego, można traktować jako czynniki sprzyjające rozwojowi przedsiębiorczości międzynarodowej.

Przedsiębiorczość międzynarodowa i wczesna internacjonalizacja przedsiębiorstwa

Pierwsze wzmianki o zjawisku tzw. wczesnej internacjonalizacji przedsiębiorstw pojawiły się już na początku lat 80 . XX w. i stanowiły zaprzeczenie ewolucyjnego modelu umiędzynarodowienia przedsiębiorstwa. Obecnie wielu autorów zamiennie stosuje pojęcia early internationalizing firms („przedsiębiorstwa wcześnie umiędzynarodowione”), 
international new ventures („międzynarodowe nowe przedsięwzięcia” w znaczeniu przedsiębiorstw) czy born globals („przedsiębiorstwa globalne od założenia”, „przedsiębiorstwa globalne od początku” lub po prostu „urodzeni globaliści”). Inni traktują born globals jako osobną i jednocześnie szczególną grupę w ramach koncepcji wczesnej internacjonalizacji. W tym drugim podejściu born globals mogą być utożsamiane z najbardziej proaktywną grupą przedsiębiorstw wcześnie umiędzynarodowionych, czyli - zgodnie z propozycją B.M. Oviatta i P.P. McDougall - z nowymi przedsiębiorstwami globalnymi (global start-up) (Wach, 2012).

Nie ulega wątpliwości, że od początku badań nad wczesną internacjonalizacją zauważalny jest problem z operacjonalizacją pojęcia born globals. Jego sprecyzowanie wymagałoby określenia m.in. takich wielkości, jak: skala operacji zagranicznych, rodzaj tych operacji i ich lokalizacja (liczba i położenie obsługiwanych krajów - rynków zagranicznych), a także czas, liczony od założenia przedsiębiorstwa, w którym należy osiągnąć określoną skalę operacji na rynkach zagranicznych. Jak do tej pory nie wypracowano konsensusu w tej sprawie (Knight, Cavusgil, 2005; Nowiński, 2006; Jarosiński, 2013; Fan, Phan, 2007; Ratajczak-Mrozek, 2015). Co więcej, w nowszych ujęciach spotyka się często definiowanie born globals przy zastosowaniu zestawu kryteriów jakościowych (np. globalna wizja założyciela/menedżerów, unikatowość produktu). Podkreśla się przy tym, że kryteria jakościowe pozwalają na wnikliwszą identyfikację i charakterystykę zjawiska wczesnej internacjonalizacji, choć z kolei kryteria ilościowe ułatwiają jednoznaczną operacjonalizację zjawiska i dobór prób do badań nad tymi przedsiębiorstwami (Duliniec, 2011a).

Born globals można zdefiniować w sensie ogólnym jako przedsiębiorstwa, które praktycznie od początku swojej działalności są zorientowane na obsługę rynków zagranicznych. Mimo że ewolucyjny model internacjonalizacji nie określał dokładnych ram czasowych, w których powinny zawierać się kolejne etapy umiędzynarodowienia, to jednak sposób działania niektórych przedsiębiorstw i dynamika internacjonalizacji nieporównywalna z podejściem stopniowym, ewolucyjnym, uzasadniają mówienie o nich jako o stosunkowo nowym zjawisku (Oczkowska, 2013). W przypadku born globals dystans psychiczny nie odgrywa tak ważnej roli jak w modelu uppsalskim, ponieważ poszukują one za granicą przede wszystkim możliwości wykorzystania swoich unikalnych zasobów i/lub niszy rynkowej o charakterze transnarodowym. Dokonując wyboru formy wejścia i funkcjonowania na rynkach zagranicznych, born globals mogą zdecydować się na pominięcie niektórych etapów internacjonalizacji i rozpocząć ten proces nie od eksportu pośredniego, ale od form bardziej zaawansowanych, wymagających większego zaangażowania na rynkach zagranicznych (aczkolwiek mogą poprzestać właśnie na eksporcie pośrednim).

Niektórzy badacze zauważają, że nie powinno się używać pojęcia born globals w odniesieniu do wszystkich przedsiębiorstw wcześnie umiędzynarodowionych, ponieważ wiele $\mathrm{z}$ nich nigdy nie osiąga (nie tylko natychmiast po założeniu) zasięgu globalnego, a jedynie zasięg międzynarodowy. Określenie „global” jest w związku z tym krytykowane za nieuzasadnione wyolbrzymianie istoty geograficznego zasięgu działania tego rodzaju przedsiębiorstw (Crick, 2009).

Nie wnikając w kwestie terminologiczne i definicyjne dotyczące born globals, należy zwrócić uwagę na ścisły i bezpośredni związek przedsiębiorczości międzynarodowej z przyczynami powstawania tego rodzaju przedsiębiorstw. Można mówić o co najmniej trzech grupach czynników sprzyjających wczesnej internacjonalizacji i powstawaniu born globals. Są to: 1 . nowe warunki rynkowe, 2. rozwój technologii w zakresie produkcji 
oraz transportu i komunikacji, 3. kwalifikacje i doświadczenie zasobów ludzkich (w tym założycieli i menedżerów), umożliwiające zachowania przedsiębiorcze i skuteczne wykorzystanie szans oferowanych przez nowe otoczenie rynkowe (Madsen, Servais, 1997; Berliński, 2006).

Pierwsze dwie grupy czynników związane są ze zmianami otoczenia międzynarodowego, które odpowiednio wykorzystane w ramach podejścia przedsiębiorczego mogą być źródłem sukcesu w obsłudze rynków zagranicznych. Nowe warunki otoczenia rynkowego polegają na tym, że postępujące zmiany o charakterze ekonomicznym, technologicznym i społecznym doprowadziły do spadku znaczenia korzyści skali jako wiodącego źródła przewagi konkurencyjnej na rynkach zagranicznych. Ogromny postęp w zakresie technologii produkcji, transportu oraz technologii komunikacyjnych i informacyjnych znacząco zredukował dotychczas bardzo wysokie koszty działalności międzynarodowej, a tym samym spowodował, że jest ona bardziej dostępna także dla mniej zasobnych podmiotów gospodarczych, czyli małych i średnich przedsiębiorstw.

Jednocześnie zmieniają się potrzeby i zachowania konsumpcyjne odbiorców dóbr i usług. W wielu przypadkach produkty zestandaryzowane zastępowane są przez ofertę wyspecjalizowaną i dostosowaną do oczekiwań konkretnego klienta. Powoduje to konieczność specjalizacji przedsiębiorstw i zdobywania tzw. nisz rynkowych, często o charakterze transnarodowym. Wiele małych i średnich przedsiębiorstw, zamiast konkurować z dużymi korporacjami o nieporównywalnych zasobach, zdecydowało się na wypełnianie powstających w wielu obszarach nisz rynkowych, co niejednokrotnie okazało się źródłem sukcesu także w skali międzynarodowej. Inną przyczyną zmieniającego się otoczenia są coraz krótsze cykle życia produktów na skutek dużej zmienności potrzeb i pragnień współczesnych konsumentów. Sytuacja taka również sprzyja małym i średnim przedsiębiorstwom, którym łatwiej jest szybko reagować na zmiany zachodzące po stronie popytu i odpowiednio dostosowywać swój produkt do zmieniających się oczekiwań odbiorców (Mróz, 2013; Dąbrowska i in., 2015).

Wśród przyczyn powstawania born globals wymienia się kwalifikacje i doświadczenie zasobów ludzkich, w tym głównie założycieli i menedżerów przedsiębiorstwa. Jest to zagadnienie ściśle powiązane $\mathrm{z}$ przedsiębiorczością międzynarodową $\mathrm{w}$ aspekcie podmiotowym. Szczególnym wyróżnikiem born globals jest posiadanie przez założycieli i menedżerów globalnej wizji rozwoju już z chwilą powstania pomysłu na biznes, a także wdrażanie tego pomysłu w życie, w czym pomaga tzw. świadomość globalna (global mindset). Świadomość globalna może być rozumiana jako zdolność postrzegania różnic kulturowych, otwartość na nie, a także umiejętność radzenia sobie z nimi, co przejawia się w proaktywnym i wizjonerskim zachowaniu menedżera przygotowanego do podejmowania ryzyka w budowaniu relacji i związanych z nimi wielokierunkowych zależności ponad granicami państw (Jarosiński, 2013).

Globalna i odważna wizja rozwoju, inicjatywa, innowacyjność oraz kompetencje założycieli i kadry menedżerskiej powszechnie traktowane są jako podstawowe wewnętrzne przesłanki sukcesu born globals (Duliniec, 2007; Duliniec, 2011b; Gabrielsson i in., 2008). Zauważono, że born globals często są zakładane przez ludzi, którzy mieli wcześniejsze doświadczenie międzynarodowe w danej branży i/lub przebywali dłużej za granicą w krajach, do których w pierwszej kolejności jest kierowana oferta produktowa nowo powstałego przedsiębiorstwa. Zwraca się uwagę na wykształcenie założycieli i menedżerów przedsiębiorstwa, znajomość języków obcych, mobilność, otwartość na kontakty 
międzykulturowe, doświadczenie z nauki lub pracy za granicą, sieć własnych formalnych i nieformalnych kontaktów. Powyższe elementy określane są jako swoiste „geny” sprzyjające szybkiej internacjonalizacji przedsiębiorstwa. Globalna wizja i strategia skierowana do globalnego rynku (segmentu rynku) oznacza podejmowanie znacznego ryzyka, w czym pomaga umiejętność sprawnego znajdowania okazji rynkowych i znajomość sposobów realizowania koncepcji przyspieszonej internacjonalizacji. W takich przypadkach proces wewnętrznego gromadzenia wiedzy o rynkach zagranicznych, a w konsekwencji internacjonalizacja przedsiębiorstwa, może przebiegać szybko i sprawnie. Jednocześnie podkreśla się, że na świecie rośnie liczba przedsiębiorców i menedżerów o orientacji kosmopolitycznej, nieodczuwających dystansu psychicznego w odniesieniu do rynków zagranicznych i odważnie podejmujących globalne wyzwania (Duliniec, 2007; Duliniec, 2011a; Duliniec, 2011b; Przybylska, 2010).

Rola osoby założyciela jest mocno zaakcentowana w koncepcjach powstawania i rozwoju born globals. Wskazuje się przy tym, że rozpatrywanie historii born globals powinno sięgać głębiej niż do momentu formalnego założenia. Założyciele i menedżerowie tego rodzaju przedsiębiorstw dysponują najczęściej dużym doświadczeniem międzynarodowym oraz licznymi kontaktami osobistymi i zawodowymi, co stanowi doskonałą podstawę do ekspansji na rynki zagraniczne, a także jest źródłem przedsiębiorczości - motywacji i ambicji stworzenia międzynarodowego przedsiębiorstwa. Można powiedzieć, że to założyciele i menedżerowie wnoszą wspomniany „gen” przedsiębiorczości międzynarodowej do nowo utworzonego podmiotu, co ujawnia się przed formalnym założeniem przedsiębiorstwa (Madsen Servais, 1997; Berliński, 2006).

E.S. Rasmussen, T.K. Madsen i F. Evangelista próbują odpowiedzieć, w jaki sposób poprzednie doświadczenia i kontakty zagraniczne założyciela wpływają na jego sposób

Ryc. 4. Proces powstawania „przedsiębiorstwa globalnego od początku” wg E.S. Rasmussena, T.K. Madsena i F. Evangelisty

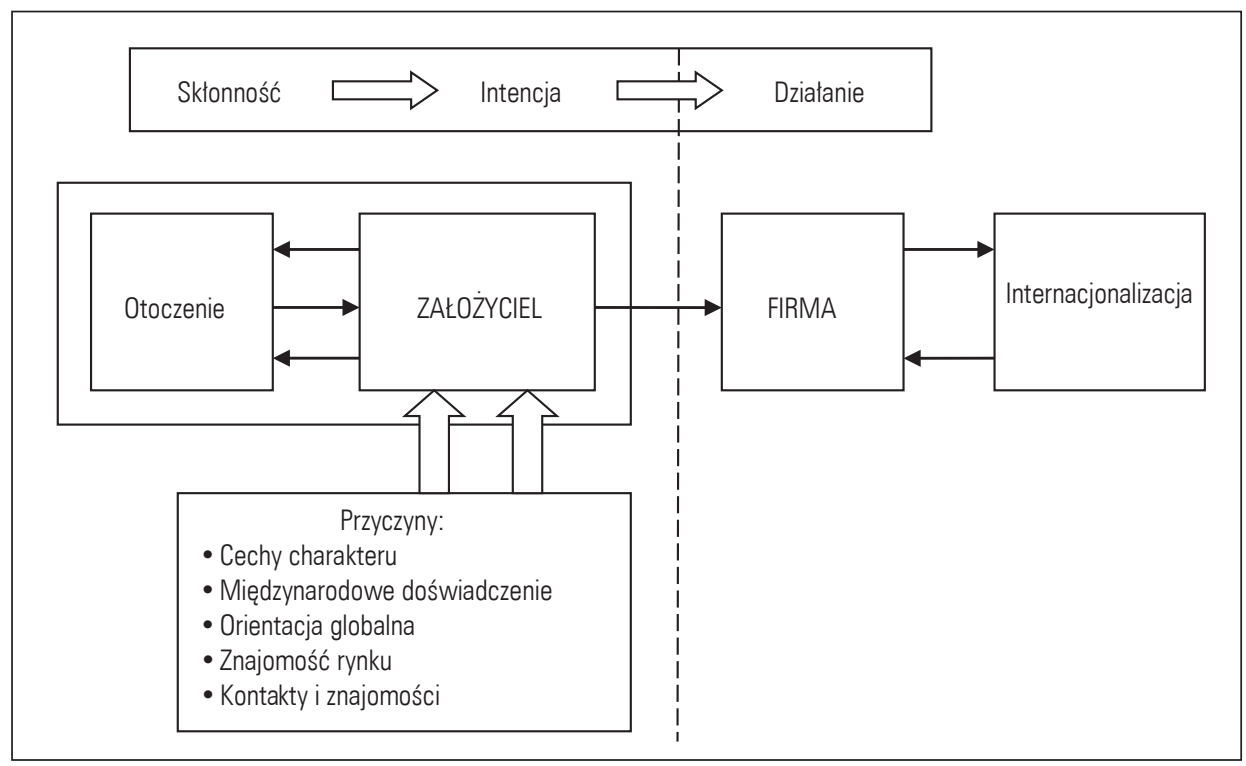

Źródło: Rasmussen, Madsen, Evangelista (2001: 81. Za: Berliński, 2006: 140) 
postrzegania przedsiębiorstwa pod kątem szans i możliwości na obcych rynkach. Proces powstawania born globals traktowany jest przez nich jako interakcja między założycielem a innymi uczestnikami rynku. Jednocześnie podkreśla się znaczenie dwóch powiązanych ze sobą pojęć w procesie powstawania born globals. Pierwszym z nich jest sensemaking, czyli sposób interpretacji rzeczywistości oraz postrzegania przedsiębiorstwa w kontekście międzynarodowym przez założyciela, na co niewątpliwie mają wpływ przeszłość założyciela nie tylko o charakterze zawodowym, ale również osobistym (ukończone studia, znajomość języków obcych, swobodne funkcjonowanie w otoczeniu międzynarodowym kosmopolityzm), wiedza o danym rynku, kontakty zagraniczne. Z kolei drugim pojęciem jest „networking”, czyli umiejscowienie założyciela w określonym systemie wzajemnych powiązań o charakterze międzynarodowym, w tym przede wszystkim jego zawodowe i prywatne kontakty $\mathrm{z}$ innymi menedżerami za granicą. W analizowanym modelu (ryc. 4) powstawanie born globals jest postrzegane jako proces składający z następujących po sobie faz, które można traktować jednocześnie jako fazy przedsiębiorczości międzynarodowej. Są to: skłonność (propensity), intencja (intention) oraz działanie (action) (Rasmussen, Madsen, Evangelista, 2001. Za: Berliński, 2006).

\section{Zakończenie}

Analiza literatury przedmiotu wskazuje, że żadna z teorii internacjonalizacji przedmiotu nie ma uniwersalnego charakteru i zastosowania niezależnie od typu przedsiębiorstwa, branży, kraju pochodzenia, czasu funkcjonowania itp. Szczegółowe rozważania dotyczące internacjonalizacji, jej motywów, przebiegu, realizowanych strategii obsługi rynków zagranicznych wymagałyby rozróżnienia procesów internacjonalizacji zachodzących w poszczególnych sektorach, w przedsiębiorstwach działających na jednym rynku lub niewielkiej liczbie rynków oraz w przedsiębiorstwach wielonarodowych i globalnych, a także w przedsiębiorstwach małych, średnich i dużych.

Podobnie problematyka przedsiębiorczości międzynarodowej jak dotąd nie doczekała się jednej spójnej teorii, która by w sposób wyczerpujący i satysfakcjonujący przynajmniej większość badaczy wyjaśniała jej istotę. W poszczególnych teoriach internacjonalizacji, w tym w zaprezentowanym w artykule modelu tradycyjnym (sekwencyjnym) oraz w koncepcji wczesnej internacjonalizacji można znaleźć elementy świadczące o zachowaniach przedsiębiorczych założycieli czy menedżerów. Model uppsalski, mimo że obecnie traktowany jest jako tradycyjny, a zdaniem niektórych - wręcz przestarzały, co do swej istoty nie stracił na znaczeniu. W praktyce wciąż wiele przedsiębiorstw przechodzi przez proces internacjonalizacji w sposób stopniowy, wkraczając na coraz to nowe rynki geograficzne i coraz bardziej odległe w sensie dystansu psychicznego, a jednocześnie wykorzystuje formy internacjonalizacji wymagające rosnącego zaangażowania zasobów. Gromadzenie wiedzy i doświadczenia - zachodzące w różnym tempie w różnych przedsiębiorstwach sprzyja ujawnianiu postaw przedsiębiorczych.

Z kolei koncepcja wczesnej internacjonalizacji może być traktowana jako bliższa powszechnemu rozumieniu przedsiębiorczości. Mimo że zjawisko born globals zostało zauważone stosunkowo niedawno, doczekało się wielu opracowań wyjaśniających jego istotę i uzasadniających coraz większą powszechność. Większość publikacji ma jednak charakter ściśle opisowy i skupia się na konkretnych sektorach gospodarki lub krajach, w których zaobserwowano wczesną internacjonalizację przedsiębiorstw. Wydaje się, że 
w badaniach dotyczących internacjonalizacji przedsiębiorstwa i przedsiębiorczości międzynarodowej wskazane jest podejście kompromisowe, sprowadzające się do eklektycznego wykorzystania dorobku różnych teorii w zależności od szeroko rozumianego kontekstu procesu internacjonalizacji przedsiębiorstwa.

\section{Literatura}

\section{References}

Berliński, M. (2006). Firmy globalne od początku. Zeszyty Naukowe Kolegium Gospodarki Światowej, $20,132-151$.

Bradley, F. (1999). International Marketing Strategy. London: Prentice Hall Europe.

Crick, D. (2009). The Internationalization of Born Global and International New Venture SMEs. International Marketing Review, 26(4-5), 453-476.

Dąbrowska, A., Bylok, F., Janoś-Kresło, M., Kiełczewski, D., Ozimek, I. (2015). Kompetencje konsumentów: innowacyjne zachowania, zrównoważona konsumpcja. Warszawa: PWE.

Duliniec, E. (2007). Internacjonalizacja przedsiębiorstw i marketing na rynkach zagranicznych. W: E. Duliniec (red.). Marketing międzynarodowy. Uwarunkowania, instrumenty, tendencje. Warszawa: Szkoła Główna Handlowa.

Duliniec, E. (2011a). Koncepcje przedsiębiorstw wcześnie umiędzynarodowionych. Rozważania terminologiczne. Gospodarka Narodowa, 1-2, 63-80.

Duliniec, E. (2011b). Przedsiębiorstwa wcześnie umiędzynarodowione - uwarunkowania i rozwój. Gospodarka Narodowa, 5-6, 1-20.

Etemad, H. (2004). International Entrepreneurship as a Dynamic Adaptive System: Toward a Grounded Theory. Journal of International Entrepreneurship, 2, 5-59.

Fan, T., Phan, P. (2007). International New Ventures: Revisiting the Influences Behind the Born-Global Firm. Journal of International Business Studies, 38, 1113-1131.

Gabrielsson, M., Kirpalani, V.H.M., Dimitratos, P., Solberg, C.A., Zucchella, A. (2008). Born Globals: Propositions to Help Advance the Theory. International Business Review, 17, 21-44.

Gorynia, M., Jankowska, B. (2007). Teorie internacjonalizacji. Gospodarka Narodowa, 10.

Jarosiński, M. (2013). Procesy i modele internacjonalizacji polskich przedsiębiorstw. Warszawa: Szkoła Główna Handlowa.

Johanson, J., Vahlne, J.E. (1977). The Internationalization Process of the Firm: A Model of Knowledge Development and Increasing Foreign Markets Commitments. Journal of Internationalization Business Studies, 8(1), 23-32.

Johanson, J., Vahlne, J.E. (2009). The Uppsala Internationalization Process Model Revisited: From Liability of Foreignness to Liability of Outsidership. Journal of International Business Studies, 40, 1411-1431.

Johanson, J., Wiedersheim-Paul, F. (1975). The Internationalization of the Firm: Four Swedish Cases. Journal of Management Studies, October, 12(3), 305-323.

Jones, M.V., Coviello, N., Kwan Tang, Y. (2011). International Entrepreneurship Research (1989-2009): A Domain Ontology and Thematic Analysis. Journal of Business Venturing, 26, 632-659.

Knight, G.A., Cavusgil, S.T. (2005). A Taxonomy of Born-Global Firms. Management International Review, 45, 15-35.

Kraśnicka, T. (2008). Przedsiębiorczość międzynarodowa jako odrębny obszar badań. W: T. Kraśnicka (red.), Przedsiębiorczość międzynarodowa. Aspekty teoretyczne i praktyczne. Katowice: Wydawnictwo Akademii Ekonomicznej w Katowicach, 11-19.

Madsen, T.K., Servais, P. (1997). The Internationalisation of Born Globals: An Evolutionary Process? International Business Review, 6(6), 561-583.

Morawczyński, R. (2008). Przedsiębiorczość międzynarodowa. Kraków: Wydawnictwo Uniwersytetu Ekonomicznego. 
Mróz, B. (2013). Konsument w globalnej gospodarce. Trzy perspektywy. Warszawa: Szkoła Główna Handlowa.

Nowacki, F. (2013). Implikacje globalizacji i regionalizacji dla przedsiębiorczości międzynarodowej. Przegląd Organizacji, 5, 4-9.

Nowacki, F. (2014). Przedsiębiorczość międzynarodowa a relacje sieciowe - wpływ na kształtowanie współpracy na rynku usług. Marketing i Rynek, 11, 14-21.

Nowiński, W. (2006). Wczesna internacjonalizacja przedsiębiorstw - nowy obszar badań. Gospodarka Narodowa, 11-12, 87-99.

Oczkowska, R. (2013). „Urodzeni globaliści” jako nowoczesna koncepcja internacjonalizacji przedsiębiorstw. Przegląd Organizacji, 4, 3-7.

Polowczyk, J. (2012). Wpływ ekonomii behawioralnej na zarządzanie strategiczne w świetle badań bibliometrycznych. Przegląd Organizacji, 6, 3-8.

Przybylska, K. (2009). Znaczenie dystansu psychicznego w procesie internacjonalizacji polskich przedsiębiorstw. W: E. Okoń-Horodyńska (red.), Przedsiębiorczość jako niewykorzystane źródło sukcesu polskiej gospodarki, Warszawa: PTE, 307-324.

Przybylska, K. (2010). Born global - nowa generacja małych polskich przedsiębiorstw. Gospodarka Narodowa, 7-8. , 63-84.

Rasmussen, E.S., Madsen, T.K., Ewangelista, F. (2001). The Founding of the Born Global Company in Denmark and Australia: Sensemaking and Networking. Asia Pacific Journal of Marketing and Logistics, 13. , 75-107.

Ratajczak-Mrozek, M. (2015). Czas w badaniach nad internacjonalizacją przedsiębiorstw. Gospodarka Narodowa, 4.

Rymarczyk, J. (2004). Internacjonalizacja i globalizacja przedsiębiorstw. Warszawa: PWE.

Wach, K. (2012). Europeizacja malych i średnich przedsiębiorstw. Rozwój przez umiędzynarodowienie. Warszawa: Wydawnictwo Naukowe PWN.

Wach, K. (2015). Przedsiębiorczość jako czynnik rozwoju społeczno-gospodarczego: przegląd literatury. Przedsiębiorczość - Edukacja, 11, 24-36.

Wach, K. (2017a). Entrepreneurial Growth of Small and Medium-Sized Enterprises. Przedsiębiorczość $i$ Zarzadzanie, 12, 405-414.

Wach, K. (2017b). Orientacja przedsiębiorcza a wiedza w początkowym i dojrzałym etapie procesu internacjonalizacji przedsiębiorstw. Studia Ekonomiczne. Zeszyty Naukowe Uniwersytetu Ekonomicznego w Katowicach, 319, 268-282.

Wiatrak, A.P. (2008). Przedsiębiorczość korporacyjna - istota, uwarunkowania i podstawowe obszary. Problemy Zarządzania, 2, 39-50.

Ireneusz Drabik, doktor nauk ekonomicznych w zakresie ekonomii, adiunkt w Instytucie Prawa Administracji i Ekonomii, na Wydziale Politologii Uniwersytetu Pedagogicznego im. KEN w Krakowie. Zainteresowania naukowe skupia na zagadnieniach dotyczących zarządzania, marketingu, międzynarodowych stosunków gospodarczych i bezpieczeństwa.

Ireneusz Drabik, PhD, Pedagogical University of Cracow, Faculty of Political Science, Institute of Law, Administration and Economics. He holds a $\mathrm{PhD}$ in economic sciences. He is an assistant professor. His research interests focus on issues related to management, marketing, international economic relations and security.

\section{Adres/Address:}

Uniwersytet Pedagogiczny im. Komisji Edukacji Narodowej w Krakowie

Wydział Politologii

Instytut Prawa, Administracji i Ekonomii

ul. Podchorążych 2

30-084 Kraków, Polska

e-mail: i.drabik@wp.pl 